\title{
Effects of Silage Soluble Nitrogen Components on Metabolizable Protein Concentration: A Meta-Analysis of Dairy Cow Production Experiments
}

\author{
P. Huhtanen, ${ }^{\star 1}$ M. Rinne, $†$ and J. Nousiainen $¥$ \\ *Department of Animal Science, 269 Morrison Hall, Cornell University, Ithaca NY 14853-4801 \\ †MTT Agrifood Research Finland, Animal Production Research, Fl-31600, Jokioinen, Finland \\ $\ddagger$ Valio Ltd., Farm Services, PO Box 10, FI-00039, Valio, Finland
}

\section{ABSTRACT}

A meta-analysis based on 253 treatment means from 80 dairy cow production experiments was conducted to estimate the effects of the silage water-soluble $\mathrm{N}$ components on milk production, milk urea $\mathrm{N}$ concentration, and the efficiency of $\mathrm{N}$ utilization in milk production. The original experiments were conducted to study forage treatments (e.g., digestibility, fermentation quality, or wilting). Both the level and composition of concentrates were fixed within an experiment. Silage soluble $\mathrm{N}(\mathrm{g} / \mathrm{kg}$ of $\mathrm{N})$ was divided into ammonia $\mathrm{N}$ and soluble nonammonia $\mathrm{N}$, which was determined without the use of protein precipitants; that is, soluble nonammonia $\mathrm{N}$ as defined here encompassed proteins, peptides, and free AA. Metabolizable protein was calculated as AA absorbed from the small intestine by using constant values for ruminal protein degradability and intestinal digestibility of undegraded protein. Metabolizable energy and protein intakes were used as independent variables in regression models investigating the effects of soluble $\mathrm{N}$ components on energy-corrected milk and milk protein yields. A mixed regression model was used to account for between-experiment variations; that is, the response of fixed factors was studied within experiments. Silage soluble N components did not affect the energy-corrected milk yield when used in bivariate models with metabolizable energy intake. Solubility of silage $\mathrm{N}$ had a negative effect on milk protein yield when included in the model with metabolizable protein. However, this effect was almost completely related to ammonia $\mathrm{N}$, whereas the effect of soluble nonammonia $\mathrm{N}$ was nonsignificant and negligible. The effects of soluble $\mathrm{N}$ components on milk urea $\mathrm{N}$ concentration and efficiency of $\mathrm{N}$ utilization in milk production were consistent with milk production responses. A lack of milk production responses to silage soluble nonammonia $\mathrm{N}$ suggested that the partition of silage $\mathrm{N}$ into soluble and

Received April 30, 2007.

Accepted November 29, 2007.

${ }^{1}$ Corresponding author: pjh87@cornell.edu insoluble $\mathrm{N}$ (excluding ammonia $\mathrm{N}$ ) did not markedly influence silage metabolizable protein concentration. Analysis of silage $\mathrm{N}$ solubility has limited value in practical feed evaluation, and silage metabolizable protein concentration can be estimated with reasonable accuracy by using constant values for ruminal protein degradability and intestinal digestion of undegraded feed protein.

Key words: ammonia nitrogen, soluble nonammonia nitrogen, milk protein yield, grass silage

\section{INTRODUCTION}

The requirement of $\mathrm{MP}$ of ruminants is met from 2 sources, microbial protein synthesized in the rumen, and feed protein that escapes microbial degradation in the rumen. Forages provide both microbial protein and undegraded feed protein. Undegraded feed protein can be determined by ruminal in situ incubation in nylon bags (Ørskov and McDonald, 1979; Hvelplund and Weisbjerg, 2000), or alternatively by in vitro incubation (Broderick, 1994). The effective protein degradability (EPD) is generally computed from the kinetic parameters estimated from the in situ degradation curve by the model of Ørskov and McDonald (1979). This model divides the degradable feed CP into fractions $a$ and $b$. Fraction $a$ is the proportion of CP that is degraded instantly at time $\mathrm{t}=0$, and $b$ is the time-dependent fraction, which is potentially degradable at a fractional rate $c$.

The limitations of the in situ method are well recognized (Michalet-Doreau and Ould-Bah, 1992; Nozière and Michalet-Doreau, 2000). One of the major problems of the in situ technique is related to the rapidly degradable $a$ fraction, which, according to the Ørskov and McDonald (1979) model, is degraded at an infinite rate with no escape from the rumen. This CP fraction includes not only the rapidly degradable NPN sources, but also soluble proteins that are not instantaneously degraded and small undegraded particles that are washed out of the bags without degradation. In the Cornell Net Carbohydrate and Protein System for eval- 
uating cattle diets (Sniffen et al., 1992), the estimation of MP is based on chemical fractionation, but this system also assumes no or very little escape of soluble AA fractions. Ideally, the $a$ fraction is equivalent to forage NPN and can be quantified chemically as the proportion of buffer-soluble $\mathrm{N}$ that is not precipitated by TCA (Broderick, 1994).

If the assumptions of the Ørskov and McDonald (1979) model were correct, the MP concentration of silages would show considerable variation because of the large variability in silage NPN (ammonia $\mathrm{N}+$ amine $\mathrm{N}+\operatorname{amino} \mathrm{N}+$ peptide $\mathrm{N}$ ) concentration, and this hypothesis has been tested by using the in situ technique. In a comprehensive analysis of 136 silages (Yan and Agnew, 2004), the proportion of silage soluble $\mathrm{N}$ in total $\mathrm{N}$ was strongly and positively related to the concentration of $a$ fraction and EPD, and the supply of MP from RUP should decrease with increasing proportion of soluble $\mathrm{N}$ in total $\mathrm{N}$. However, there is considerable in vivo evidence of the outflow of soluble amino $\mathrm{N}$ fractions in the liquid phase from the rumen (Hristov and Broderick, 1996; Choi et al., 2002; Volden et al., 2002). Progress in predicting the supply of RUP from forages has been slow, partly because of the shortcomings of the experimental techniques and partly because of the lack of reliable validation data. Validation of the in situ degradation data by flow measurements of $\mathrm{N}$ fractions (microbial and undegraded feed $\mathrm{N}$ ) in cannulated animals is laborious and technically difficult. Another alternative used to examine the effects of $\mathrm{N}$ solubility on feed MP concentration is meta-analysis of the data from milk production experiments.

Our objective was to examine the effect of variation in silage $\mathrm{N}$ solubility on utilization of silage $\mathrm{N}$ by conducting a meta-analysis of the data from dairy cow production experiments. The concentration of MP in silage was computed by using a constant EPD value for all silages, irrespective of $\mathrm{N}$ solubility. The hypothesis was that a possible negative effect of increased $\mathrm{N}$ solubility on MP supply should be reflected in reduced milk protein yield (MPY), efficiency of $\mathrm{N}$ utilization, or increased MUN concentration relative to the estimated MP or CP supply.

\section{MATERIALS AND METHODS}

\section{Data Acquisition and Calculations}

Mean treatment values were collected from Finnish dairy cow trials that used ad libitum feeding of grass silage or mixed silage diets so that, at a maximum, $50 \%$ of grass silage was substituted for legume or wholecrop cereal silages. The forages were supplemented with concentrate feeds differing in both amount and composition between, but not within, the experiments.
When several concentrate treatments were used within a trial, they were considered as separate experiments in the statistical analysis. The data included 253 treatment means from 80 experiments (see Appendix).

The prerequisite for an experiment to be included in the data set was that silage and total DMI, milk production, and adequate silage characterization (plant species, DM concentration, in vivo or in vitro digestibility, and fermentation quality, including proportions of soluble $\mathrm{N}$ and ammonia $\mathrm{N}$ in total $\mathrm{N}$ ) were reported. Soluble NAN (SNAN) concentration $(\mathrm{g} / \mathrm{kg}$ of $\mathrm{N})$ in silage was calculated as soluble $\mathrm{N}$ concentration minus ammonia $\mathrm{N}$ concentration $(\mathrm{g} / \mathrm{kg}$ of $\mathrm{N})$. Silage extracts were prepared for soluble $\mathrm{N}$ and ammonia $\mathrm{N}$ analyses as follows: fresh silage was mixed with cold water in a blender for $3 \mathrm{~min}$, kept refrigerated for $0.5 \mathrm{~h}$, and mixed again for $3 \mathrm{~min}$, filtered through Büchner funnels under suction, and centrifuged for $10 \mathrm{~min}$ at a $g$-force of 1,960. The extract was then analyzed for soluble $\mathrm{N}$ with the Kjeldahl method and for ammonia $\mathrm{N}$ according to McCullough (1967). No protein precipitants were used; that is, SNAN encompassed free AA, peptides, and proteins. Milk urea $\mathrm{N}$ concentration was analyzed in 62 studies including 162 treatment means. Milk urea N concentration was analyzed as ammonia in composite samples by using the methods described by Nousiainen et al. (2004).

Milk yield was expressed as ECM yield calculated according to Sjaunja et al. (1991). Milk composition used to compute ECM yield was analyzed by an infrared milk analyzer. Silage ME concentration (MJ/kg of DM) was calculated as $0.016 \times$ in vivo or in vitro digestible $\mathrm{OM}$ concentration in DM ( $\mathrm{g} / \mathrm{kg}$ of DM), and that of concentrate feeds was calculated by using analyzed chemical composition and published digestibility coefficients (MTT-Agrifood Research Finland, 2006) for each ingredient. The MP concentrations, expressed as AA absorbed from the small intestine, were calculated by using a modification of the Scandinavian AAT-PBV system (MTT-Agrifood Research Finland, 2006). The system uses constant values for EPD ( 0.85 for grass silages, and 0.80 for legume and whole-crop silages) and intestinal digestibility of RUP (0.82). The MP from microbial protein $(\mathrm{g} / \mathrm{kg}$ of $\mathrm{DM})$ was calculated as 0.179 $\times$ [digestible crude carbohydrates $(\mathrm{g} / \mathrm{kg}$ of $\mathrm{DM})+\mathrm{EPD}$ $\times \mathrm{CP}(\mathrm{g} / \mathrm{kg}$ of $\mathrm{DM})] \times 0.70 \times 0.85$, where the coefficients are the efficiency of microbial protein synthesis (0.179), proportion of AA N in microbial $\mathrm{N}(0.70)$, and digestibility of microbial protein (0.85). Digestible crude carbohydrates were derived by using the same methods as for computing ME concentrations.

\section{Statistical Analysis}

The data were analyzed by using the mixed model procedure of SAS (Littell et al., 1996). The model was 
Table 1. Description of the data

\begin{tabular}{|c|c|c|c|c|c|}
\hline Item & $\mathrm{n}$ & Mean & $\mathrm{SD}$ & Minimum & Maximum \\
\hline \multicolumn{6}{|l|}{ Production data } \\
\hline \multicolumn{6}{|l|}{ DMI (kg/d) } \\
\hline Silage & 253 & 11.5 & 1.63 & 7.8 & 17.4 \\
\hline Total & 253 & 19.2 & 2.45 & 13.7 & 25.2 \\
\hline \multicolumn{6}{|l|}{ Production } \\
\hline Milk $(\mathrm{kg} / \mathrm{d})$ & 253 & 26.7 & 4.55 & 16.5 & 38.2 \\
\hline ECM (kg/d) & 253 & 28.1 & 4.53 & 18.4 & 40.2 \\
\hline Protein $(g / d)$ & 253 & 858 & 153.5 & 546 & 1,265 \\
\hline Protein ( $\mathrm{g} / \mathrm{kg}$ of milk) & 253 & 32.3 & 1.37 & 28.7 & 35.9 \\
\hline Milk N/N intake (g/kg) & 253 & 286 & 29.2 & 208 & 364 \\
\hline MUN (mg/L) & 186 & 12.9 & 3.8 & 3.9 & 26 \\
\hline \multicolumn{6}{|l|}{ Feed composition data } \\
\hline \multicolumn{6}{|l|}{ In silage (g/kg of DM) } \\
\hline $\mathrm{CP}$ & 253 & 158 & 24.2 & 108 & 234 \\
\hline $\mathrm{NDF}$ & 183 & 530 & 43.9 & 441 & 645 \\
\hline Digestible OM & 253 & 666 & 43.0 & 495 & 738 \\
\hline $\mathrm{MP}$ & 253 & 83.4 & 4.29 & 67.3 & 93.8 \\
\hline \multicolumn{6}{|l|}{ In silage $(\mathrm{g} / \mathrm{kg}$ of total $\mathrm{N})$} \\
\hline Ammonia $\mathrm{N}$ & 253 & 55 & 23.4 & 12 & 150 \\
\hline Soluble N & 253 & 574 & 86.7 & 274 & 782 \\
\hline Soluble NAN & 253 & 520 & 88.1 & 203 & 729 \\
\hline
\end{tabular}

$\mathrm{Y}=\mathrm{B}_{0}+\mathrm{B}_{1} \mathrm{X}_{1 \mathrm{ij}}+\mathrm{b}_{0}+\mathrm{b}_{1} \mathrm{X}_{1 \mathrm{ij}}+\mathrm{B}_{2} \mathrm{X}_{2 \mathrm{ij}}+\mathrm{B}_{3} \mathrm{X}_{3 \mathrm{ij}}+\mathrm{e}_{\mathrm{ij}}$, where $\mathrm{B}_{0}+\mathrm{B}_{1} \mathrm{X}_{1 \mathrm{ij}}+\mathrm{B}_{2} \mathrm{X}_{2 \mathrm{ij}}+\mathrm{B}_{3} \mathrm{X}_{3 \mathrm{ij}}$ are the fixed effects, and $\mathrm{b}_{0}, \mathrm{~b}_{1}$, and $\mathrm{e}_{\mathrm{ij}}$ are the random experimental effects (intercept and slope), where $i=1 \ldots 80$ studies and $j=1$. .. $\mathrm{n}_{\mathrm{i}}$ values. The ECM yield, MPY, MUN concentration, and efficiency of $\mathrm{N}$ utilization were used as dependent $\mathrm{Y}$ variables. In the multivariate models only, the first independent variable was a random factor. The models estimating the effects of dependent variables on MPY did not converge when ME or MP intake was used as a random factor; therefore, only random intercept was used in those models. Variation in experimental protocols, animal types, and laboratory assays would contribute to experiment effects in these regressions. Tables 2,3 , and 4 present root mean squared errors (RMSE) and $\mathrm{R}^{2}$ values after adjusting for the random effect of experiment. The rationale and further details of using a mixed model analysis to integrate quantitative findings from multiple studies are described by St-Pierre (2001).

\section{RESULTS}

The experimental data are described in Table 1. There was considerable variation in both silage composition and animal parameters. Variation both in silage soluble $\mathrm{N}$ and SNAN concentrations ( $\mathrm{g} / \mathrm{kg}$ of $\mathrm{N}$ ) was large. Variation in soluble $\mathrm{N}$ concentration was strongly associated with SNAN concentration [soluble N $(\mathrm{g} / \mathrm{kg}$ of $\mathrm{N}$ ) $=81+0.95 \times \mathrm{SNAN} ; P<0.001, \mathrm{R}^{2}=0.93$ ], whereas ammonia $\mathrm{N}$ concentration was not significantly associated with soluble $\mathrm{N}$ concentration. The proportions of soluble $\mathrm{N}$ and SNAN in total $\mathrm{N}$ were negatively $(P<$ $0.001)$ related to silage $\mathrm{CP}$ concentration $(\mathrm{g} / \mathrm{kg}$ of $\mathrm{DM})$, but the relationships were not very strong $\left(R^{2}=0.045\right.$ and 0.111 , respectively).

The ECM yield was closely associated with ME intake (Table 2). The mean ECM response to increased ME supply was $0.106 \mathrm{~kg} / \mathrm{MJ}$ of ME. The effect of silage CP concentration on ECM yield was significantly negative $(P=0.04)$ when it was used in a bivariate model together with ME intake. None of the soluble $\mathrm{N}$ components (expressed as $\mathrm{g} / \mathrm{kg}$ of total $\mathrm{N}$ ) had a significant effect on ECM yield when used in a bivariate model with $\mathrm{ME}$ intake, or in a multiple regression model with $\mathrm{ME}$ intake and silage $\mathrm{CP}$ concentration.

Intake of MP, estimated according to the Finnish modification of the AAT-PBV system, explained the MPY within an experiment precisely as indicated by the low RMSE and high $\mathrm{R}^{2}$ values (Table 3 ). Residual standard deviation in MPY within an experiment was $15.1 \mathrm{~g} / \mathrm{d}$; that is, the MP supply explained a high proportion of the relatively small variation between the diets within an experiment. Silage CP, ammonia N, and soluble $\mathrm{N}$ concentrations had a negative effect on MPY when used in a bivariate model with MP intake. Similarly, the effects of ammonia $\mathrm{N}$ and soluble $\mathrm{N}$ remained significant when silage $\mathrm{CP}$ concentration was included in the model. However, the effect of SNAN was not significant when used either as a second independent variable with MP intake or as a third variable with $\mathrm{CP}$ and ammonia $\mathrm{N}$ concentrations.

The effects of silage CP concentration and soluble $\mathrm{N}$ components on MUN concentration are presented in Table 4. The MUN concentration was closely associated with silage CP concentration. In a bivariate model, silage ammonia $\mathrm{N}$ concentration had a positive $(P<0.01)$ 
Table 2. Effects of ME intake (MJ/d), silage CP concentration ( $\mathrm{g} / \mathrm{kg}$ of $\mathrm{DM})$, and soluble $\mathrm{N}$ components (g/ $\mathrm{kg}$ of $\mathrm{N})$ on ECM yield $(\mathrm{kg} / \mathrm{d})$

\begin{tabular}{|c|c|c|c|c|c|c|c|c|c|c|}
\hline $\mathrm{X}_{1}$ & $\mathrm{X}_{2}$ & $\mathrm{X}_{3}$ & Intercept $^{1}$ & Slope $_{1}{ }^{2}$ & Slope $_{2}$ & $P$-value & $\mathrm{Slope}_{3}$ & $P$-value & $\mathrm{RMSE}^{3}$ & $\mathrm{R}^{2}$ \\
\hline ME & & & 5.25 & 0.106 & & & & & 0.507 & 0.977 \\
\hline ME & CP & & 5.78 & 0.109 & -0.0072 & 0.05 & & & 0.515 & 0.979 \\
\hline ME & $\mathrm{NH}_{3}-\mathrm{N}$ & & 4.99 & 0.107 & 0.0013 & 0.60 & & & 0.508 & 0.977 \\
\hline ME & SNAN $^{4}$ & & 5.55 & 0.107 & -0.0008 & 0.39 & & & 0.508 & 0.977 \\
\hline ME & Soluble N & & 5.53 & 0.106 & -0.0005 & 0.56 & & & 0.508 & 0.977 \\
\hline ME & $\mathrm{CP}$ & $\mathrm{NH}_{3}-\mathrm{N}$ & 5.43 & 0.110 & -0.0076 & 0.04 & 0.0020 & 0.42 & 0.517 & 0.979 \\
\hline ME & $\mathrm{CP}$ & SNAN & 6.05 & 0.109 & -0.0074 & 0.04 & -0.0005 & 0.41 & 0.516 & 0.978 \\
\hline ME & $\mathrm{CP}$ & Soluble N & 6.19 & 0.109 & -0.0075 & 0.04 & -0.0007 & 0.41 & 0.517 & 0.978 \\
\hline
\end{tabular}

${ }^{1}$ Intercept $(P<0.01)$.

${ }^{2}$ Slope $_{1}(P<0.01)$.

${ }^{3} \mathrm{RMSE}=$ root mean squared error.

${ }^{4} \mathrm{SNAN}=$ soluble NAN.

effect on MUN concentration, but the effects of soluble $\mathrm{N}$ and SNAN concentrations were negligible and nonsignificant. When ammonia $\mathrm{N}$ and SNAN concentrations were used together with silage CP concentration, only the effect of ammonia $\mathrm{N}$ was significant.

Dietary CP concentration explained most of the variation in the efficiency of $\mathrm{N}$ utilization within experiments (Table 4). The effects of ammonia $\mathrm{N}$ and soluble $\mathrm{N}$ concentrations were significant when included in the model with CP concentration. The slope was 3.5 -fold for ammonia $\mathrm{N}$ compared with that of soluble $\mathrm{N}$. The concentration of SNAN had no influence on the efficiency of $\mathrm{N}$ utilization.

\section{DISCUSSION}

\section{Silage Composition}

The silages displayed a wide range in both CP concentration and proportions of soluble $\mathrm{N}$ components in total $\mathrm{N}$. On average, silage fermentation quality was good, as indicated by the relatively low proportion of ammonia $\mathrm{N}$ $(55 \mathrm{~g} / \mathrm{kg}$ of $\mathrm{N}$ ) for mostly low-DM silages (mean DM concentration of $275 \mathrm{~g} / \mathrm{kg}$ ). The lack of global correlation between ammonia $\mathrm{N}$ and soluble $\mathrm{N}$ proportions in total $\mathrm{N}$ suggests that proteolysis and deamination in the silo are not related, but the within-experiment relationship estimated by a mixed model analysis showed a positive relationship between ammonia and soluble $\mathrm{N}$ [ammonia $\mathrm{N}(\mathrm{g} / \mathrm{kg}$ of $\mathrm{N})=1.3( \pm 15.2)+0.09( \pm 0.25) \times$ soluble $\mathrm{N}$ $(\mathrm{g} / \mathrm{kg}$ of $\mathrm{N})]$. Soluble $\mathrm{N}$ was analyzed as water-soluble $\mathrm{N}$, which may result in slightly higher values (Rinne et al., 1997) compared with the buffer solubility determined according to Licitra et al. (1996). The conclusions of the current study can, however, be extended to situations in which buffer-soluble $\mathrm{N}$ is used, because in a comparison conducted at MTT-Agrifood Research Finland (M. Rinne; unpublished data) the proportions of water-soluble $\mathrm{N}$ and borate buffer-soluble $\mathrm{N}$ in total silage $\mathrm{N}$ were closely correlated [borate buffer-soluble $\mathrm{N}(\mathrm{g} / \mathrm{kg}$ of $\mathrm{N})=0.829 \times$ water-soluble $\mathrm{N}(\mathrm{g} / \mathrm{kg}$ of $\mathrm{N})+$

Table 3. The effects of MP intake ( $\mathrm{g} / \mathrm{d}$ ), silage CP concentration ( $\mathrm{g} / \mathrm{kg}$ of DM), and silage soluble $\mathrm{N}$ components $(\mathrm{g} / \mathrm{kg}$ of $\mathrm{N})$ on milk protein yield $(\mathrm{g} / \mathrm{d})$

\begin{tabular}{|c|c|c|c|c|c|c|c|c|c|c|}
\hline $\mathrm{X}_{1}$ & $\mathrm{X}_{2}$ & $\mathrm{X}_{3}$ & Intercept $^{1}$ & Slope $_{1}^{2}$ & Slope $_{2}$ & $P$-value & Slope $_{3}$ & $P$-value & $\mathrm{RMSE}^{3}$ & $\mathrm{R}^{2}$ \\
\hline $\mathrm{MP}^{4}$ & & & 100 & 0.429 & & & & & 15.1 & 0.98 \\
\hline MP & $\mathrm{CP}$ & & 109 & 0.442 & -0.197 & 0.04 & & & 15.1 & 0.98 \\
\hline MP & $\mathrm{NH}_{3}-\mathrm{N}$ & & 138 & 0.414 & -0.190 & $<0.01$ & & & 14.5 & 0.98 \\
\hline MP & SNAN $^{5}$ & & 111 & 0.432 & -0.031 & 0.25 & & & 15.1 & 0.98 \\
\hline MP & Soluble N & & 127 & 0.430 & -0.047 & 0.05 & & & 15.2 & 0.98 \\
\hline MP & $\mathrm{CP}$ & $\mathrm{NH}_{3}-\mathrm{N}$ & 139 & 0.426 & -0.147 & 0.13 & -0.170 & 0.01 & 14.6 & 0.986 \\
\hline MP & $\mathrm{CP}$ & SNAN & 125 & 0.446 & -0.219 & 0.03 & -0.040 & 0.14 & 15.1 & 0.986 \\
\hline MP & $\mathrm{CP}$ & Soluble N & 138 & 0.443 & -0.210 & 0.03 & -0.050 & 0.03 & 14.9 & 0.98 \\
\hline MP & $\mathrm{NH}_{3}-\mathrm{N}$ & SNAN & 143 & 0.416 & -0.182 & 0.01 & -0.019 & 0.46 & 14.6 & 0.985 \\
\hline
\end{tabular}

${ }^{1}$ Intercept $(P<0.01)$.

${ }^{2} \mathrm{Slope}_{1}(P<0.01)$.

${ }^{3} \mathrm{RMSE}=$ root mean squared error.

${ }^{4} \mathrm{MP}=\mathrm{MP}$ calculated assuming constant effective protein degradability (RDP/CP) and intestinal digestibility of RUP for silage CP.

${ }^{5} \mathrm{SNAN}=$ soluble NAN. 
Table 4. The effects of silage CP concentration ( $\mathrm{g} / \mathrm{kg}$ of $\mathrm{DM})$ and silage soluble $\mathrm{N}$ components (g/kg of $\mathrm{N})$ on MUN concentration and efficiency of $\mathrm{N}$ utilization

\begin{tabular}{|c|c|c|c|c|c|c|c|c|c|c|}
\hline $\mathrm{X}_{1}$ & $\mathrm{X}_{2}$ & $\mathrm{X}_{3}$ & Intercept & Slope $_{1}{ }^{1}$ & Slope $_{2}$ & $P$-value & Slope $_{3}$ & $P$-value & $\mathrm{RMSE}^{2}$ & $\mathrm{R}^{2}$ \\
\hline \multicolumn{11}{|c|}{$\mathrm{MUN}^{3}(\mathrm{mg} / \mathrm{dL})$} \\
\hline $\mathrm{CP}$ & & & -2.64 & 0.103 & & & & & 0.61 & 0.941 \\
\hline $\mathrm{CP}$ & $\mathrm{NH}_{3}-\mathrm{N}$ & & -2.83 & 0.100 & 0.012 & $<0.01$ & & & 0.58 & 0.945 \\
\hline $\mathrm{CP}$ & SNAN $^{4}$ & & -2.20 & 0.102 & -0.001 & 0.67 & & & 0.61 & 0.940 \\
\hline $\mathrm{CP}$ & Soluble N & & -3.21 & 0.103 & 0.001 & 0.55 & & & 0.60 & 0.942 \\
\hline $\mathrm{CP}$ & $\mathrm{NH}_{3}-\mathrm{N}$ & SNAN & -1.85 & 0.098 & 0.013 & $<0.01$ & -0.002 & 0.32 & 0.59 & 0.944 \\
\hline \multicolumn{11}{|c|}{$\mathrm{N}$ utilization ${ }^{5}[$ milk N/N intake $(\mathrm{g} / \mathrm{kg})]$} \\
\hline $\mathrm{CP}$ & & & 524 & -1.51 & & & & 0.01 & 6.2 & 0.932 \\
\hline $\mathrm{CP}$ & $\mathrm{NH}_{3}-\mathrm{N}$ & & 525 & -1.49 & -0.070 & $<0.01$ & & 0.14 & 6.0 & 0.937 \\
\hline $\mathrm{CP}$ & SNAN & & 523 & -1.50 & -0.003 & 0.81 & & $<0.01$ & 6.1 & 0.933 \\
\hline $\mathrm{CP}$ & Soluble N & & 533 & -1.51 & -0.020 & 0.02 & & 0.46 & 6.1 & 0.933 \\
\hline $\mathrm{CP}$ & $\mathrm{NH}_{3}-\mathrm{N}$ & SNAN & 525 & -1.49 & -0.070 & $<0.01$ & 0.000 & 0.98 & 6.0 & 0.936 \\
\hline
\end{tabular}

${ }^{1}$ Slope $_{1}(P<0.001)$.

${ }^{2} \mathrm{RMSE}=$ root mean squared error.

${ }^{3}$ Intercept for MUN all $(P>0.09)$.

${ }^{4}$ SNAN $=$ soluble NAN.

${ }^{5}$ Intercept for $\mathrm{N}$ utilization all $(P<0.01)$.

$\left.80 ; \mathrm{R}^{2}=0.840, \mathrm{n}=26\right]$. In addition to $\mathrm{NPN}$, silage soluble $\mathrm{N}$ contains small amounts of soluble proteins (e.g., Rinne et al., 1997; Krizsan and Randby, 2007).

\section{Milk Yield}

The effects of silage soluble $\mathrm{N}$ components on milk production were examined by using ECM as a dependent variable and ME intake as an independent variable in the model to eliminate the effects of the changes in milk composition and feed intake in response to changes in silage fermentation characteristics (Huhtanen et al., 2007) that are often associated with changes in soluble N concentration. Silage N solubility was significantly $(P<0.001)$ correlated with silage lactic acid concentration, which has a strong effect on both milk fat and protein concentration (Huhtanen et al., 2003). The increase in ECM yield per MJ of ME (0.106) associated with an increase in silage DMI (Table 2) in response to improved D-value (digestible $\mathrm{OM}, \mathrm{g} / \mathrm{kg}$ of DM) or fermentation quality, increased DM concentration, or replacement of grass silage with legume or wholecrop silages corresponds to values reported in previous reviews (Agnew et al., 1998; Huhtanen, 1998). Silage soluble N components had no specific effects on ECM yield at fixed ME intakes. However, silage CP concentration was negatively associated with ECM yield (Table 2; $P=0.04$ ). This may be related to the energy requirement associated with the excretion of incremental $\mathrm{N}$ in the urine (Tyrrel et al., 1970). The cost of energy for $\mathrm{N}$ excretion reported by Tyrrel et al. (1970) was 7.2 $\mathrm{kcal}$ of $\mathrm{ME} / \mathrm{g}$ of excess $\mathrm{N}$ or $3.0 \mathrm{MJ} / 100 \mathrm{~g}$ of excess $\mathrm{N}$. Although the adverse effect of silage CP concentration on ECM yield was significant, the magnitude of the effect was relatively small. When using the mean silage DMI (11.5 kg) and the ME requirements for kilograms of ECM produced (5.2 MJ/kg of ECM), the observed effect $(-0.0074 \mathrm{~kg}$ of ECM per $1 \mathrm{~g} / \mathrm{kg}$ in silage $\mathrm{CP})$ corresponds to $2.1 \mathrm{MJ}$ of $\mathrm{ME} / 100 \mathrm{~g}$ of additional $\mathrm{N}$ from silage. This value is slightly smaller than that suggested by Tyrrel et al. (1970). The relatively small energy loss for excreting additional $\mathrm{N}$ to urine agrees with Reynolds (2006), who suggested that energy loss associated with secretion of additional $\mathrm{N}$ to urine is lower than previously reported. When soluble $\mathrm{N}$ components were used together with $\mathrm{ME}$ intake and $\mathrm{CP}$ concentration to predict ECM yield, the effect of CP remained significant and those of soluble $\mathrm{N}$ components were insignificant. This supports the view that the negative effects of silage CP concentration on ECM yield were associated with $\mathrm{CP}$ per se rather than with the form in which $\mathrm{N}$ was present in the silage.

\section{MPY}

Intake of MP predicted MPY accurately within an experiment (RMSE $15.1 \mathrm{~g} / \mathrm{d}$ ). The standard error (0.0128) of the slope (0.423) was small and the interaction between the slope and the intercept was nonsignificant $(P=0.83)$, suggesting that the relatively simple model predicted MP concentration of silage-based diets within an experiment accurately.

A constant EPD and intestinal digestibility of RUP were used to calculate MP values in the present study. However, it is well established that in situ EPD of forages decreases with advancing maturity (e.g., Lindberg, 1988; Van Vuuren et al., 1991). Similarly, the silage EPD value was positively related to OM digestibility 
and negatively related to NDF concentration in a recent in situ study by Yan and Agnew (2004) that included 136 silages. These data suggest that using a constant EPD would underestimate the MP concentration of silages with advancing maturity. However, in the present study the effects of silage NDF concentration $(P=0.16)$ or $\mathrm{D}$-value $(P=0.87)$ were not significant when they were used as a second independent factor in a bivariate model with MP to predict MPY. This suggests that if the supply of RUP was under-predicted with advancing maturity of silages, it was not utilized by the cows for milk protein synthesis. It is possible that the maturity effects on EPD and digestibility of RUP compensate for each other so that the net supply of digestible RUP as a proportion of silage $\mathrm{CP}$ is not markedly influenced by forage maturity. Reduced intestinal digestibility of RUP estimated by the mobile bag technique (Vanhatalo et al., 1996) and increasing ADIN concentration (Rinne et al., 1997) indicates reduced intestinal digestibility of RUP with advancing maturity of grass.

Considering the weaknesses of routine experimental techniques in estimating EPD and intestinal RUP digestibility accurately, it is questionable whether the accuracy of predicting MP values of the forages can be improved by feed-specific determinations compared with constant values. This is in agreement with a comparison of several protein evaluation systems (Schwab et al., 2005). The German system, which estimates MP supply from $\mathrm{ME}$ and $\mathrm{CP}$ intake (i.e., constant EPD and intestinal digestibility of RUP), predicted MPY responses to mixed diets better than did most other systems.

The negative effect of silage CP concentration on MPY at a constant MP intake may be due to an overestimation of the ATP supply from RDP compared with carbohydrates (Tamminga, 1979). On the basis of the regression coefficient of $\mathrm{CP}(-0.23)$ and mean MP utilization (0.424), the MP intake was overestimated by 5.5 $\mathrm{g} / \mathrm{d}[(0.23 \times 10) / 0.424]$ per $10 \mathrm{~g} / \mathrm{kg}$ of $\mathrm{DM}$ increase in silage CP concentration. At the mean silage DMI (11.5 $\mathrm{kg}$ ), a difference of $10 \mathrm{~g} / \mathrm{kg}$ of DM in silage CP corresponds to $10.4 \mathrm{~g}$ of MP calculated according to MTT (2006). The ratio of these numbers (approximately 0.5) suggests that the supply of ATP from microbial digestion of protein is less than that from carbohydrates.

Silage N solubility had a negative effect on MPY at a constant MP intake, but the effect can be attributed almost entirely to ammonia N. The effect of SNAN was not significant when it was included in a bivariate model with MP intake or in 3 variable models together with MP intake and silage $\mathrm{CP}$ or ammonia $\mathrm{N}$ concentration (Table 3). The lack of an effect of SNAN on MPY suggests that the assumptions of the models by Ørskov and McDonald (1979) and Sniffen et al. (1992) regard- ing infinite digestion rate of the $a$ fraction does not hold true. Omasal flow measurements have shown a considerable flow of feed SNAN, with peptides being quantitatively the most important component (Choi et al., 2002; Reynal et al., 2007). Volden et al. (2002) fed a single dose of silage soluble $\mathrm{N}$ to cows and estimated that approximately $10 \%$ of the SNAN escaped rumen degradation in the liquid phase. A similar value can be recalculated from the data of Choi et al. (2002).

Hristov and Broderick (1996) estimated the flow of $\mathrm{N}$ fractions from rumen pool sizes and fractional passage rates of rumen solid and liquid phases. Outflow of alfalfa and corn silage SNAN in the liquid phase was approximately $24 \%$ of the dietary intake. Using an inhibitor in vitro technique, Peltekova and Broderick (1996) estimated that $20 \%$ of silage SNAN escapes rumen fermentation. Hedqvist and Udén (2006), using an in vitro technique, estimated that proportionally $25 \%$ of soluble protein in ryegrass escapes ruminal degradation. Variation in the estimates of SNAN flow probably reflects methodological and dietary differences between the studies in addition to the contribution of microbial SNAN flow (Choi et al., 2002; Reynal et al., 2007).

The value of the in situ measurements is also limited for concentrate feeds with high levels of buffer-soluble $\mathrm{N}$, such as peas and lupines. Comparison of in vivo and in situ data showed that the in situ method underestimated the proportion of protein escaping from the rumen (Aufrère et al., 2001), because protein degradation is assumed to be identical to $\mathrm{N}$ disappearance in situ.

Although the degradation rate of silage soluble $\mathrm{N}$ is clearly faster than that of insoluble N (e.g., Peltekova and Broderick, 1996), the difference in EPD is smaller than could be predicted from in situ degradation rates because of the much faster passage rate of the rumen liquid phase compared with that of the particulate matter. Broderick (1994) suggested a 2-compartment kinetic model applying different degradation and passage rates for soluble and insoluble $\mathrm{N}$ fractions. Theoretically, this model is more appropriate than the model of Ørskov and McDonald (1979), which is used in most protein evaluation systems to compute EPD values from degradation kinetic data. Furthermore, computing the EPD value by using a 2-compartment model incorporating the mechanisms of selective retention of feed particles will increase ruminal degradability of insoluble protein compared with a 1-compartment system with similar total residence time (Ellis et al., 1994; Huhtanen et al., 2006).

Studies investigating the effects of limiting fermentation in the silo or drying of grass provide further evidence that decreasing $\mathrm{N}$ solubility does not decrease in vivo degradability. Restricting proteolysis in the silo by increasing the level of formic acid application did not 
increase the duodenal flow of feed $\mathrm{N}$ in sheep (Chamberlain et al., 1982) or in cattle (Jaakkola et al., 2006), but the microbial $\mathrm{N}$ flow increased linearly because of an increased supply of fermentable energy. Jaakkola and Huhtanen (1993) compared hay and silage made from the same sward and reported no difference in duodenal NAN flow and only slightly higher feed $\mathrm{N}$ flow with hay compared with silage, despite much higher $\mathrm{N}$ solubility in silage.

The data from both duodenal flow measurements and milk production trials suggest that the protein fraction protected from proteolysis by high levels of acid additives or by drying is rapidly degraded in the rumen, with the resultant differences in RUP flow being small. In contrast, Verbic et al. (1999) reported proportionally $0.41,0.32$, and 0.26 higher MP concentrations in hay than in 3 silages (untreated, wilted, and formic acid treated, respectively) made from the same sward. They used ruminal in situ incubation and urinary purine derivative excretion to estimate feed and microbial protein flow. Their MP estimates are inconsistent with duodenal $\mathrm{N}$ flow measurements and production data, which may at least partly be related to flow of SNAN in the liquid phase and that the model assumptions used may have been too simplistic to compute EPD values from the in situ data.

Two reasons may explain the negative effects of ammonia N on MPY at a constant estimated MP intake: 1) AA deaminated to ammonia in the silo do not provide energy (adenosine triphosphate) for rumen microbial protein synthesis, and 2) no AA are available for escape either in the liquid phase or as insoluble $\mathrm{N}$ in the particle phase. Discounting silage CP concentration for ammonia N decreased the prediction error of MPY from 15.1 to $14.5 \mathrm{~g} / \mathrm{d}$. Although the improvement was not large in this data set with a relatively low mean ammonia $\mathrm{N}$ concentration, using ammonia-corrected $\mathrm{CP}$ concentration in computing MP concentration can be recommended.

\section{Milk Urea N Concentration and Efficiency of $N$ Utilization}

The effects of silage soluble $\mathrm{N}$ components on MUN concentration were consistent with observed milk production responses. Milk urea $\mathrm{N}$ concentration is mainly influenced by dietary CP concentration (Broderick and Clayton, 1997; Nousiainen et al., 2004), but an increase in the excess of RDP had a stronger effect on MUN than did a corresponding increase in MP. The effects of increased proportion of silage ammonia N on MPY and MUN at a fixed MP intake or dietary CP concentration are consistent with the observations of Nousiainen (2004). He showed that MPY and MUN responses per unit increase in dietary CP concentration were negatively correlated; that is, a high MPY response was associated with a small increase in MUN with increased dietary CP concentration. Most likely, an increased proportion of silage ammonia $\mathrm{N}$ reduced the NAN flow at a fixed CP concentration, which resulted in increased net absorption of ammonia from the rumen, and consequently an increased MUN concentration.

The effect of silage ammonia $\mathrm{N}$ concentration on the efficiency of $\mathrm{N}$ utilization was statistically significant, although the magnitude of the response was rather small. However, all additional $\mathrm{N}$ excretion is likely to be urinary $\mathrm{N}$, which is more susceptible to both evaporation and leaching. The reduced efficiency of $\mathrm{N}$ utilization with increased ammonia $\mathrm{N}$ was consistent with increased MUN.

\section{CONCLUSIONS}

A meta-analysis of a large data set (253 treatment means) of the effects of silage soluble $\mathrm{N}$ components demonstrated that increased $\mathrm{N}$ solubility was associated with reduced MPY and efficiency of $\mathrm{N}$ utilization and with increased MUN concentration. However, these adverse effects can be attributed almost completely to ammonia N, whereas the proportion of silage SNAN in total $\mathrm{N}$ did not influence MPY or the efficiency of $\mathrm{N}$ utilization. The results suggest that the widely used model in estimating EPD and MP concentration in silages strongly overemphasizes the role of $\mathrm{N}$ solubility, and that the model assumption (that in situ $\mathrm{N}$ disappearance is equivalent to ruminal $\mathrm{N}$ degradation) may not be correct. The faster passage rate of the liquid phase compared with feed particles from the rumen compensates at least partly for the differences in the degradation rates of silage soluble and insoluble $\mathrm{N}$. Proportion of SNAN in silage $\mathrm{N}$ had no influence on MPY, and consequently on the true silage MP concentration. The results of the present study suggest that the value of silage soluble $\mathrm{N}$ analysis in practical feed evaluation is limited, and that silage MP concentration can be accurately estimated by using constant values for EPD and intestinal digestibility of RUP. It is unlikely that the current analytical techniques for onfarm silages are able to detect differences in silage MP concentration associated with ruminal CP degradability that are of practical significance.

\section{ACKNOWLEDGMENTS}

We are grateful to all our colleagues, especially Terttu Heikkilä, who provided information on the unpublished experiments included in the data set. 


\section{REFERENCES}

Agnew, R. E., T. Yan, and F. J. Gordon. 1998. Nutrition of the highproducing dairy cow-Energy metabolism studies. Pages 181206 in Recent Advances of Animal Nutrition. P. C. Garnsworthy, and J. Wiseman, ed. Nottingham Univ. Press, Nottingham, UK.

Aufrère, J., D. Graviou, J. P. Melcion, and C. Demarquilly. 2001. Degradation in the rumen of lupin (Lupinus albus L.) and pea (Pisum sativum L.) seed proteins: Effect of heat treatment. Anim. Feed Sci. Technol. 92:215-236.

Broderick, G. A. 1994. Quantifying forage protein quality. Pages 200228 in Forage Quality, Evaluation, and Utilization. G. C. Fahey Jr., D. R. Collins, D. R. Mertens, and L. E. Moser, ed. Am. Soc. Agron. Inc., Crop Sci. Soc. Am. Inc., and Soil Sci. Soc. Am. Inc., Madison, WI.

Broderick, G. A., and M. K. Clayton. 1997. A statistical evaluation of animal and nutritional factors influencing concentrations of nitrogen. J. Dairy Sci. 80:2964-2971.

Chamberlain, D. G., P. C. Thomas, and M. K. Wait. 1982. The rate of addition of formic acid to grass at ensilage and the subsequent digestion of the silage in the rumen and intestines of sheep. Grass Forage Sci. 37:159-164.

Choi, C. W., S. Ahvenjärvi, A. Vanhatalo, V. Toivonen, and P. Huhtanen. 2002. Quantitation of the flow of soluble non-ammonia nitrogen entering the omasal canal of dairy cows fed grass silage based diets. Anim. Feed Sci. Technol. 96:203-220.

Ellis, W. C., J. H. Matis, T. M. Hill, and M. R. Murphy. 1994. Methodology for estimating digestion and passage kinetics of forages. Pages 682-756 in Forage Quality, Evaluation, and Utilization. G. C. Fahey Jr., D. R. Collins, D. R. Mertens, and L. E. Moser, ed. Am. Soc. of Agron. Inc., Crop Sci. Soc. of Am. Inc., and Soil Sci. Soc. of Am. Inc., Madison, WI.

Hedqvist, H., and P. Udén. 2006. Measurement of soluble protein degradation in the rumen. Anim. Feed Sci. Technol. 126:1-21.

Hristov, A. N., and G. A. Broderick. 1996. Synthesis of microbial protein in ruminally cannulated cows fed alfalfa silage, alfalfa hay, or corn silage. J. Dairy Sci. 79:1627-1637.

Huhtanen, P. 1998. Supply nutrients and productive responses in dairy cows given diets based on restrictively fermented silage. Agric. Food Sci. Finl. 7:219-250.

Huhtanen, P., S. Ahvenjärvi, M. R. Weisbjerg, and P. Norgaard. 2006. Digestion and passage of fibre in ruminant. Pages $83-135$ in Ruminant Physiology. K. Sejrsen, T. Hvelplund, and M. O. Nielsen, ed. Wageningen Academic Publishers, Wageningen, the Netherlands.

Huhtanen, P., J. I. Nousiainen, H. Khalili, S. Jaakkola, and T. Heikkilä. 2003. Relationships between silage fermentation characteristics and milk production parameters: Analyses of literature data. Livest. Prod. Sci. 81:57-73.

Huhtanen, P., M. Rinne, and J. Nousiainen. 2007. Evaluation of the factors affecting silage intake of dairy cows: A revision of the relative silage dry matter intake index. Animal 1:758-770.

Hvelplund, T., and M. R. Weisbjerg. 2000. In situ techniques for the estimation of protein degradability and postrumen availability. Pages 233-258 in Forage Evaluation in Ruminant Nutrition. D. I. Givens, E. Owen, R. F. E. Axford, and H. M. Omed, ed. CABI Publishing, Wallingford, UK.

Jaakkola, S., and P. Huhtanen. 1993. The effects of forage preservation method and proportion of concentrate on nitrogen digestion and rumen fermentation in cattle. Grass Forage Sci. 48:146-154.

Jaakkola, S., V. Kaunisto, and P. Huhtanen. 2006. Volatile fatty acid proportions and microbial protein synthesis in the rumen of cattle receiving grass silage ensiled with different rates of formic acid. Grass Forage Sci. 61:282-292.

Krizsan, S. J. and A. T. Randby, 2007. The effect of fermentation quality on the voluntary intake of grass silage by growing cattle fed silage as the sole feed. J. Anim. Sci. 85:984-996.

Licitra, G., T. M. Hernandez, and P. J. Van Soest. 1996. Standardization of procedures for nitrogen fractionation of ruminant feeds. Anim. Feed Sci. Technol. 57:347-358.
Lindberg, J. E. 1988. Influence of cutting time and N fertilization on the nutritive value of timothy. 2. Estimates of rumen degradability of nitrogenous compounds. Swed. J. Agric. Res. 18:85-89.

Littell, R. C., G. A. Milliken, W. W. Stroup, and R. D. Wolfinger. 1996. SAS System for Mixed Models. SAS Inst. Inc., Cary, NC.

McCullough, H. 1967. The determination of ammonia in whole blood by direct calorimetric method. Clin. Chim. Acta 17:297-304.

Michalet-Doreau, B., and M. Y. Ould-Bah. 1992. In vitro and in sacco methods for the estimation of dietary nitrogen degradability in the rumen: A review. Anim. Feed Sci. Technol. 40:57-86.

MTT-Agrifood Research Finland. 2006. Rehutaulukot ja ruokintasuositukset (Feed tables and feeding recommendations). MTT-Agrifood Research Finland, Jokioinen, Finland. http//www.agronet.fi/ rehutaulukot. Accessed March 8, 2007.

Nousiainen, J. 2004. Development of tools for the nutritional management of dairy cows on silage-based diets. PhD Thesis. Dept. Anim. Sci. Publ. 72. University of Helsinki, Helsinki, Finland. http:// ethesis.helsinki.fi/julkaisut/maa/kotie/vk/nousiainen/. Accessed March 8, 2007.

Nousiainen, J., K. J. Shingfield, and P. Huhtanen. 2004. Evaluation of milk urea nitrogen as a diagnostic of protein feeding. J. Dairy Sci. 87:386-398.

Nozière, P., and B. Michalet-Doreau. 2000. In sacco methods. Pages 233-253 in Farm Animal Metabolism and Nutrition. J. P. F. D'Mello, ed. CABI Publishing, Wallingford, UK.

Ørskov, E. R., and I. McDonald. 1979. The estimation of protein degradability in the rumen from incubation measurements weighted according to rate of passage. J. Agric. Sci. Camb. 92:499-503.

Peltekova, V. D., and G. A. Broderick. 1996. In vitro ruminal degradation and synthesis of protein on fractions extracted from alfalfa hay and silage. J. Dairy Sci. 79:612-619.

Reynal, S. M., I. R. Ipharraguerre, M. Liñeiro, A. F. Brito, G. A. Broderick, and J. H. Clark. 2007. Omasal flow of soluble proteins, peptides, and free amino acids in dairy cows fed diets supplemented with proteins of varying ruminal degradabilities. J. Dairy Sci. 90:1887-1903.

Reynolds, C. 2006. Splanchnic amino acid metabolism in ruminants. Pages 225-248 in Ruminant Physiology. K. Sejrsen, T. Hvelplund, and M. O. Nielsen, ed. Wageningen Academic Publishers, Wageningen, the Netherlands.

Rinne, M., S. Jaakkola, and P. Huhtanen. 1997. Grass maturity effects on cattle fed silage-based diets. 1. Organic matter digestion, rumen fermentation and nitrogen utilization. Anim. Feed Sci. Technol. 67:1-17.

Schwab, C. G., P. Huhtanen, C. W. Hunt, and T. Hvelplund. 2005. Nitrogen requirements of cattle. Pages 13-70 in Nitrogen and Phosphorus Nutrition of Cattle-Reducing the Environmental Impact of Cattle Operations. E. Pfeffer and A. N. Hristov, ed. CABI Publishing, Wallingford, UK.

Sjaunja, L. O., L. Baevre, L. Junkkarinen, J. Pedersen, and J. Setälä. 1991. A Nordic proposal for an energy corrected milk (ECM) formula. Page 156 in Proc. 27th Biennial Session Int. Comm. Anim. Recording. Performance Recording of Animals: State of the Art 1990, Paris, France. EAAP Publ. No. 50. Center for Agricultural Publishing and Documentation (PUDOC), Wageningen, the Netherlands.

Sniffen, C. J., J. D. O'Connor, P. J. Van Soest, D. G. Fox, and J. B. Russell. 1992. A net carbohydrate and protein system for evaluating cattle diets. 2. Carbohydrate and protein availability. J. Anim. Sci. 70:3562-3577.

St-Pierre, N. R. 2001. Integrating quantitative findings from multiple studies using mixed model methodology. J. Dairy Sci. 84:741-755.

Tamminga, S. 1979. Protein degradation in the forestomachs of ruminants. J. Anim. Sci. 49:1615-1630.

Tyrrel, H. F., P. W. Me, and W. P. Flatt. 1970. Influence of excess protein intake on energy metabolism of the dairy cow. Pages 6972 in Energy Metabolism of Farm Animals. EAAP Publ. No. 13. A. Schurch and C. Wenk, ed. Juris Verlag, Zurich, Switzerland.

Van Vuuren, A. M., S. Tamminga, and R. S. Ketelaar. 1991. In sacco degradation of organic matter and crude protein of fresh grass 
(Lolium perenne) in the rumen of grazing dairy cows. J. Agric. Sci. Camb. 116:429-436.

Vanhatalo, A., P. Dakowski, and P. Huhtanen. 1996. Effects of stage of growth and duration of rumen incubation time on intestinal digestibility of rumen-undegradable nitrogen of grass by mobilebag method in cows. Acta Agric. Scand. Sect. A. Anim. Sci. 46:1-10.

Verbic, J., E. R. Ørskov, J. Zgajnar, X. B. Chen, and V. Znidarsic Pongrac. 1999. The effect of method of forage preservation on the protein degradability and microbial protein synthesis in the rumen. Anim. Feed Sci. Technol. 82:195-212.

Volden, H., L. T. Mydland, and V. Olaisen. 2002. Apparent ruminal degradation and rumen escape of soluble nitrogen fractions in grass and grass silage administered intraruminally to lactating dairy cows. J. Anim. Sci. 80:2704-2716.

Yan, T., and R. E. Agnew. 2004. Prediction of nutritive values in grass silages: II. Degradability of nitrogen and dry matter using digestibility, chemical composition, and fermentation data. J. Anim. Sci. 82:1380-1391.

\section{APPENDIX}

\section{List of Publications Describing the Experiments Used in the Data Analysis}

Heikkilä, T., S. Jaakkola, R. Sormunen-Cristian and T. Mela. 2000 Yellow-flowered lucerne-grass silage in milk production. Page 353-355 in Proc. 18th Gen. Mtg. Eur. Grassl. Fed., Aalborg, Denmark. Eur. Grassl. Fed.

Heikkilä, T. and V. Toivonen. 2001. Effect of harvesting methods on silage quality, intake and milk production with or without hay. Page 19-24 in Production and Utilization of Silage. Lillehammer, Norway. Royal Soc. Dev., Oslo, Norway.

Heikkilä, T., V. Toivonen, and P. Huhtanen. 1998a. Effects of and interactions between the extent of silage fermentation and protein supplementation in lactating dairy cows. Agric. Food Sci. Finland 7:329-343.

Heikkilä, T., V. Toivonen, and P. Huhtanen. 1998b. Effect of spring and autumn silage, protein and concentrate level on milk production. 17th Gen. Mtg. Eur. Grassl. Fed., Debrecen Agricultural University, Debrecen, Hungary. Grassl. Sci. Eur. 3:717-721.

Heikkilä, T., V. Toivonen, T. Keskinen, P. Parikka and T. Tupasela. 1999. Effects of two additives and harvesting methods of wilted silage and concentrate level on milk production. Page 149-150 in XIIth Int. Silage Conf.: Silage Production in Relation to Animal Performance, Animal Health, Meat and Milk Quality, Uppsala, Sweden. Swedish Agric. Univ., Uppsala, Sweden.

Heikkilä, T., V. Toivonen and T. Mela. 1992. Comparison of red clovergrass silage with grass silage for milk production. Page 388-391 in Gen. Mtg. Eur. Grassl. Fed., Lahti, Finland. MarkPrint Ltd., Lahti, Finland.

Heikkilä, T., V. Toivonen and T. Tupasela. 1997. Effect of additives on big bale silage quality and milk production. Page 119 in 48th Annu. Mtg. EAAP, Vienna, Austria. Wageningen Press, Wageningen, the Netherlands.

Heikkilä, T., V. Toivonen and H. Väätäinen. 1992. Effect of biological additives on silage quality and milk production with dairy cows.
Page 49 in 42nd Annu. Mtg. EAAP, Berlin, Germany. EAAP, Rome, Italy.

Heikkilä, T., H. Väätäinen and M. Lampila. 1988. Barley or oats for dairy cows? Page 336 in VI World Conf. Anim. Prod., Helsinki, Finland. Gummerus, Jyväskylä, Finland.

Heikkilä, T., H. Väätäinen and M. Lampila. 1989. Effect of silage quality on milk yield and composition in dairy cows. Page 177183 in Int. Symp. Production, Evaluation and Feeding of Silage, Rostock, Berlin. Oskar Kellner Inst., Rostock, Germany.

Heikkilä, T., H. Väätäinen and V. Toivonen. 1993. Effects of acid and biological additives on grass silage quality and milk production in dairy cows supplemented with concentrates containing three levels of rapeseed meal. Page 190 in 10th Int. Conf. Silage Res., Dublin, Ireland. Dublin City Univ., Dublin, Ireland.

Jaakkola, S., M. Rinne, T. Heikkilä, V. Toivonen and P. Huhtanen. 2006. Effects of restriction of silage fermentation with formic acid on milk production. Agric. Food Sci. 15:200-218.

Jaakkola, S., M. Rinne, K. Huuskonen, V. Vesterinen and P. Huhtanen. 1995. The effect of silage fermentation on the response to protein supplementation in milk production and rumen fermentation in vitro. Page 68 in VII Symp. Protein Metab. Nutr., Vale de Santarem, Portugal. Instituto Nacional de Investigatory Agraria, Lisboa, Portugal.

Jaakkola, S., E. Saarisalo and T. Heikkilä. 2003. Concentrate supplementation of dairy cow diet based on whole crop barley and wheat silage. Page 10 in NJF's 22nd Congr., Turku, Finland. MTT, Jokioinen, Finland.

Khalili, H., P. Huhtanen, K. Rinne and M. Suvitie. 1997. The effects of two levels of concentrates supplying the same amount of protein on silage intake and milk production in cows given two grass silages. Page 3 in XVIII Int. Grassl. Congr., Winnipeg, Manitoba, Saskatoon, Saskatchewan, Canada. Assoc. Manage. Centre, Calgary, Canada.

Khalili, H., A. Sairanen, J. Nousiainen and P. Huhtanen. 2005. Effects of silage made from primary or regrowth grass and protein supplementation on dairy cow performance. Livest. Prod. Sci. 96:269278.

Kokkonen, T., M. Tuori, V. Leivonen and L. Syrjälä-Qvist. 2000. Effect of silage DM content and rapeseed meal supplementation on dairy cows. 1. Milk production and feed utilisation. Anim. Feed Sci. Technol. 84:213-228.

Kuoppala, K., M. Rinne, J. Nousiainen and P. Huhtanen. 2005. The effect of harvest time of grass silage in primary growth and regrowth and the interactions between silage quality and concentrate level in milk production of dairy cows. Livest. Sci.

Rinne, M., S. Jaakkola, K. Kaustell, T. Heikkilä and P. Huhtanen. 1999. Silages harvested at different stages of grass growth v. concentrate foods as energy and protein sources in milk production. Anim. Sci. 69:251-263.

Saarisalo, E., S. Jaakkola, A. Vaari and E. Skyttä. 2003. Effect of protein supplementation of wilted silages varying in fermentation quality on milk production. Page 22 in NJF's 22nd Congr., Turku, Finland.

Shingfield, K. J., S. Jaakkola and P. Huhtanen. 2001. Effects of level of nitrogen fertilizer application and various nitrogenous supplements on milk production and nitrogen utilization of dairy cows given grass silage-based diets. Anim. Sci. 73:541-554.

Shingfield, K. J., A. Vanhatalo and P. Huhtanen. 2003. Comparison of heat-treated rapeseed expeller and solvent-extracted soya-bean meal as protein supplements for dairy cows given grass silagebased diets. Anim. Sci. 77:305-317. 